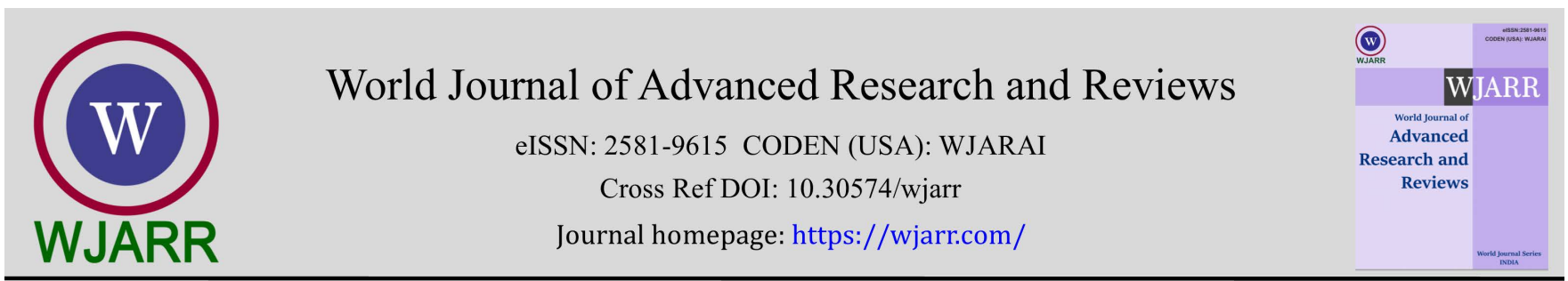

(RESEARCH ARTICLE)

\title{
The relationship between white meat consumption and consumption psychology during COVID-19 pandemic period
}

\author{
Emre Aydemir 1,* Erdener Altın ${ }^{2}$ and İnci Bilge 1 \\ ${ }^{1}$ Department of Animal Science, Faculty of Agriculture, Akdeniz University, 07070 Antalya, Turkey. \\ 2 Department of Electricity and Energy, Vocational School of Technical Sciences, Mehmet Akif Ersoy University, 15100 \\ Burdur, Turkey.
}

World Journal of Advanced Research and Reviews, 2021, 09(03), 014-019

Publication history: Received on 29 January 2021; revised on 28 February 2021; accepted on 02 March 2021

Article DOI: https://doi.org/10.30574/wjarr.2021.9.3.0076

\begin{abstract}
The COVID-19 virus, which has affected the whole world in a short time, has created various psychological effects on people. One of these effects is unconscious food consumption. During the quarantine, food consumption increased, regardless of the health and balanced diet of the people. This study was conducted across Turkey, with participants from 81 provinces were selected by chance for each city. Participants answered the questionnaire questions based on the voluntary principle. They stated that they consume food sources with high carbohydrate content during the pandemic and quarantine. In contrast, the consumption of animal products as a source of protein has not increased significantly. $73.02 \%$ of the participants especially prefer white meat as a source of animal protein. One of the most important reasons for this is that it is affordable. Especially in the last 30 years, thanks to the important developments in poultry breeding, the amount of production has increased significantly every day globally. White meat is eagerly consumed without any difference in social and economic class. When the amount of white meat consumed as a protein source during the COVID-19 pandemic was compared with the amount of white meat consumed in the previous process, it was found that there was no significant difference. In addition, it has been observed that consumption psychology has an effect on white meat consumption.
\end{abstract}

Keywords: COVID-19; White meat; Consumption psychology

\section{Introduction}

Coronavirus-2 (SARS-CoV-2), which has a worldwide pandemic effect, first appeared in Wuhan, China in December 2019 [1]. With its spread in a short time, it has become an epidemic all over the world. The world health organization had declared COVID-19 as a global epidemic on March 11, 2020 [2]. Various have been taken to prevent this epidemic. With the increase in the number of ill, curfews and quarantine measures were taken. During these measures, unconscious food consumption started due to stress in people who did not have the habit of staying home for a long time [1-21]. It has been observed in the studies that the expenditures for food increased with the pandemic [1-7-13-17]. Due to this increase, various changes have occurred in lifestyle and eating habits [16]. As a result of these observations, depending on consumption psychology; the consumption of unnecessary foods with high carbohydrate and fat content has increased. For a healthy and balanced diet, a sufficient amount of protein, fat, carbohydrate, vitamin and mineral substance needs must be met. Especially during the COVID-19 pandemic, the tendency towards foods that strengthen the immune system has increased. Animal products come first among these foods. Animal source products such as milk, eggs and meat are consumed extensively due to their high nutrient content [3-4-8-14]. Meat and eggs obtained from poultry are the cheapest products that contain the basic nutritional needs of humans. In addition, these products are heavily consumed due to their essential nutrients, high protein and low-fat content. Poultry meat production has

\footnotetext{
${ }^{*}$ Corresponding author: Emre Aydemir

Department of Animal Science, Faculty of Agriculture, Akdeniz University, 07070 Antalya, Turkey.
} 
increased significantly in the last 30 years, depending on the developments in poultry breeding worldwide. When the developments in poultry in our country are examined, production was made in small family businesses in the 1970s. In the 1980s, it is seen that thanks to the structural changes that occurred with the increase of industrialization, integrated facilities were established and the contracted production model started to be implemented. With the government support and the personal efforts of entrepreneurs, the number of modern production facilities increased in the 1990s. In addition, the production capacity has also rapidly developed and high standard products have been started. With these developments, the annual production increase increased significantly between the years 1990-2000, the annual consumption per person increased from $3.8 \mathrm{~kg}$ to $14.5 \mathrm{~kg}$, and it increased approximately 3.8 times in the period from 1990 to 2008 . Turkey broiler industry has entered into the top ten worldwide by the year 2008. Production capacity increases year on year, reaching 2.23 million tons of poultry meat production in Turkey in 2018, the annual per capita consumption of poultry meat is also reported to have reached 22 kilograms [6].

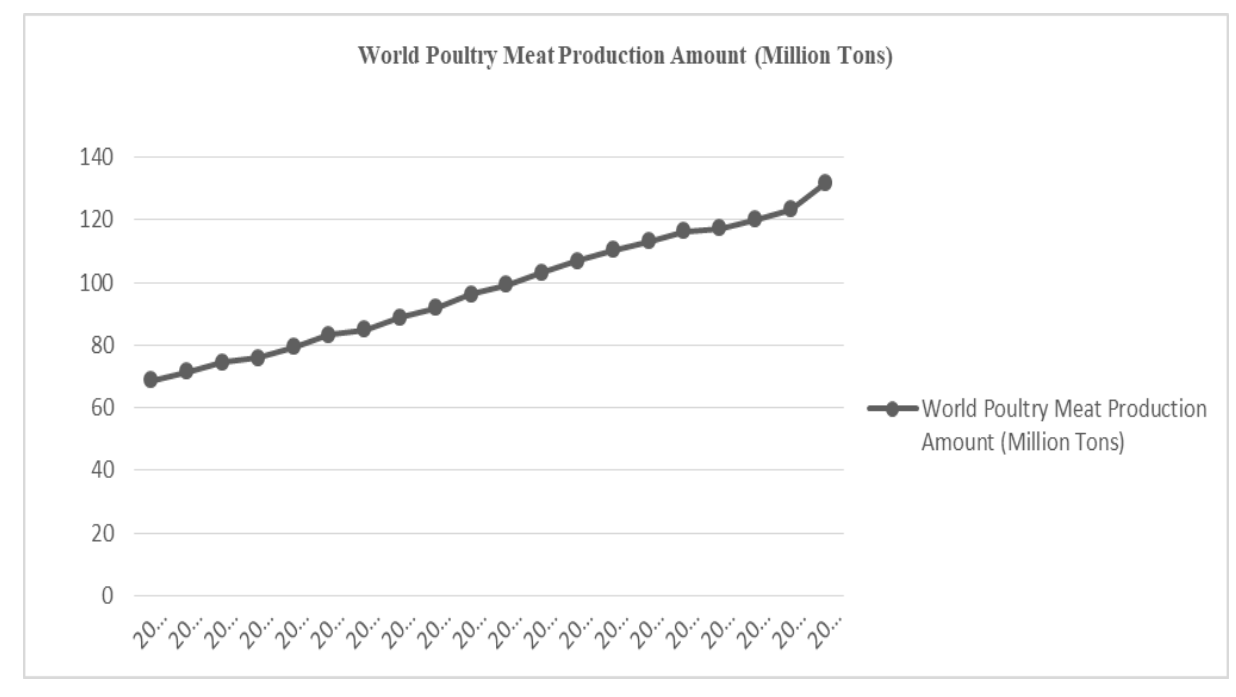

Figure 1 Poultry Meat Production ln World (6)

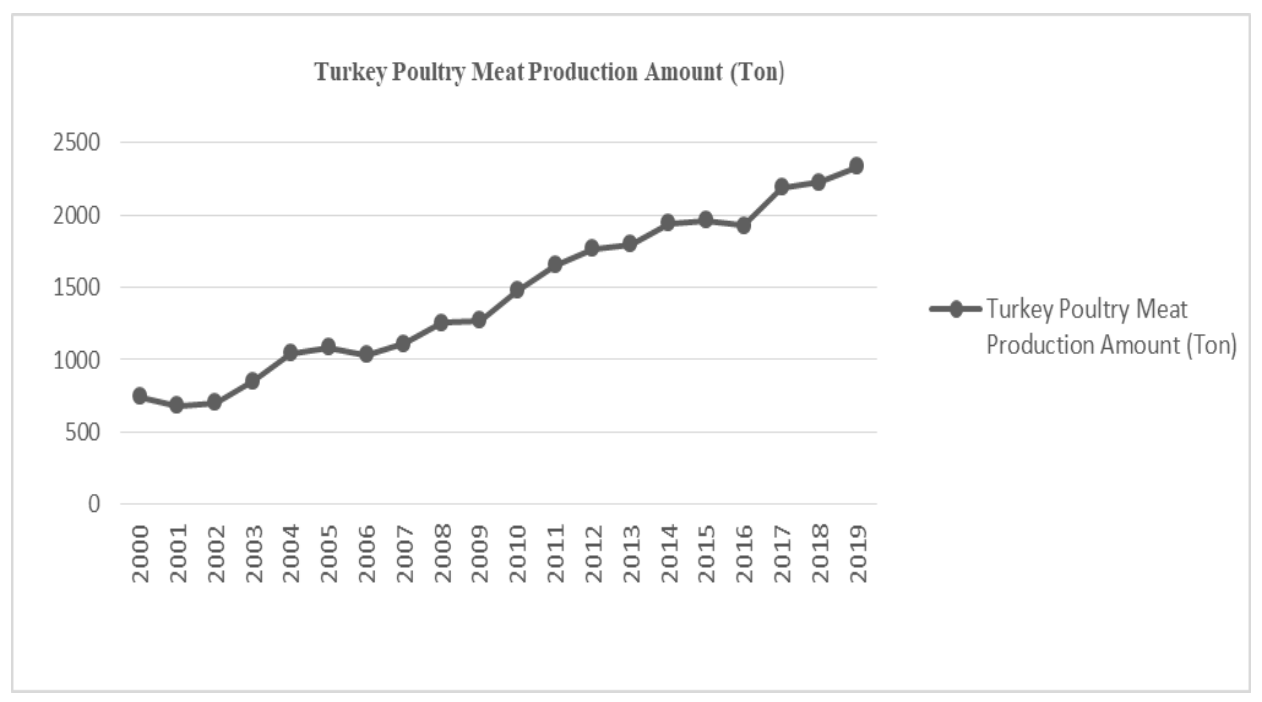

Figure 2 Poultry Meat Production ln Turkey (6)

World poultry meat production was 68.8 million tons in 2000, while today it is over 123.7 million tons of poultry meat production. Poultry production has increased significantly throughout the world in the last thirty years. Especially, 
when the production amount between 2000 and 2019 is examined; It was estimated to be $68.8,71.5,74.4,75.9,79.3$, 83.2, 84.9, 88.9, 91.8, 96.3, 99.2, 103.2, 106.9, 110.3, 113.2, 116.4, 117.2, 120.1, 123.2 and 131.4 million tons [6]. Today, $37.27 \%$ of world meat production is obtained from chicken, pork has a share of $36.52 \%$, bovine meat $21.69 \%$ and sheep meat with a share of $4.51 \%$ [6]. While the total amount of meat produced today is 330.5 million tons, FAO's statement stated that the total amount of meat will reach 357.5 million tons in 2025. In addition, it is estimated that the amount of poultry meat will preserve its position and increase its share. Especially in the world of chicken meat production in the United States, Brazil, China, European Union, India, Russia, Mexico, Argentina, Turkey, Thailand, Indonesia is located in the first row [6].

\subsection{Chicken meat nutrient content}

The nutrient sources required for the nutrition of living things are of vegeFigure and animal sources. Among the products of animal sources, the most consumed meat is obtained from poultry. The reason why products obtained from broiler chickens are consumed is that they are affordable and grow in a short time. Meat and eggs obtained from poultry are among the cheapest products that contain the basic nutritional needs of humans. When the nutrients of chicken meat are examined, there are protein, fat, carbohydrate, cellulose, sugar, mineral, vitamin, cholesterol and fatty acids. When the minerals content is examined, there is Calcium, iron, magnesium, phosphorus, potassium, sodium and zinc. [3-8-4-21]. When the vitamin content is examined, there are A, B, B-6, B-12, C, D, D2, D3, folate, thiamine, niacin and riboflavin [21]. All this nutrient content, $85 \%$ genetically; $15 \%$ of it varies depending on feeding and environmental conditions [10]. There are approximately 20-22 grams of protein in 100 grams of chicken meat [USDA 2016].

\subsubsection{Consumption Psychology}

Consumption varies depending on the needs and requirements of living things. When the reasons for this change are examined; the living creature's situation, environmental conditions, psychological and physiological, etc. are factors [59-15]. Consumption for living beings is defined as the consumption of products obtained by producers in order to meet their essential basic needs such as eating and drinking [11-12-20]. In another definition, it is also defined as purchasing a product we need by paying its price [5-9-15]. With increasing brand and product options, purchasing a needed product differs. Especially, various advertisements, news, presentations, etc. made by mass media. it closely affects consumption psychology [9-20]. In addition, consumer preferences change depending on physiological, psychological, geographical conditions, social and economic structure [20].

\section{Material and methods}

In this study, the consumer perspective of poultry meat whose production and consumption are increasing day by day was examined. In the study, weekly and monthly poultry meat consumption frequency and total kg of meat consumed by consumers were asked. The relationship between the nutritional content of chicken meat and its consumption, psychology, social and economic structure has been examined. In the survey with 32 questions, gender and age criteria were examined; but not taken into account. In addition, the relationship between the COVID-19 pandemic period and white meat consumption was also examined.

By using the variance analysis technique for the results obtained from the study, whether there is a difference between the brands was revealed at the $5 \%$ significance level. All statistical analyzes were made using SPSS statistical software.

\section{Results}

This study conducted across Turkey, COVID-19 is valid for the first 5 months of the pandemic period. In the study, the questionnaire questions were answered by a total of 2430 people on a voluntary basis. 30 people were chosen for each province depending on chance. While $81.68 \%$ of the participants are women; $18.31 \%$ is male. However, gender criteria were not considered in the study. $69.42 \%$ of the participants stated that the consumption frequency increased during the COVID-19 period. Especially $73.02 \%$ of the participants stated that they preferred white meat in general as a source of animal protein. The most important reason for this is that it is the cheapest source of animal protein. When the weekly white meat consumption is examined for the amount ranges specified in the questionnaire questions, it has been determined that it varies between 1-1.5 kilograms on average. When the monthly consumption amount is examined, it is determined that it varies between $3-4 \mathrm{~kg}$. While $90.65 \%$ of the participants care about the expiration date in product consumption; $4.19 \%$ brand, $2.59 \%$ price and $2.57 \%$ consider meat color as quality criteria. In addition, when more than one criterion was examined, $78.43 \%$ of the participants are taken into consideration as the brand, price and expiry date as quality criteria; 13.41 of the brand, expiry date and meat color; $8.16 \%$ preferred the price as brand and meat color. $82.44 \%$ of the participants stated that the brand criteria have an effect on consumption psychology. When the piece 
meat consumption was examined, it was found that $41.84 \%$ was wing, $31.69 \%$ leg and $26.47 \%$ breast. Especially during the COVID-19 period, $57.83 \%$ of the participants preferred to consume whole chicken. In the study, it was determined that $33.45 \%$ of the participants have general knowledge about poultry breeding. In the study, it was observed that $78.32 \%$ of the participants did not have information about the average protein content of 100 grams of chicken meat. This shows that the participants do not have enough information about poultry breeding and products. $74.11 \%$ of the participants know that the broiler chickens are raised in a short time. Worldwide white production is in different amounts. Therefore, $69.09 \%$ of the participants stated that they were caused by social and economic reasons, $16.46 \%$ from geographical reasons, $6.86 \%$ from reproductive preferences and $7.59 \%$ from the supply-demand relationship. Breeding preference and supply-demand relationship, social psychology, religious views and so on. It was stated that it was caused by reasons. As a result, during the COVID-19 period, the consumption of carbohydrate-containing food sources has increased. In addition, it was found that white meat consumption did not increase significantly during the COVID-19 epidemic. The indication of this is that the consumption of white meat is conscious. In addition, it has been determined that there is a significant relationship between brand and consumption psychology in the consumption of white meat.

\subsection{Brand and consumption relationship}

In the study, the consumption of white meat products sold in the market was examined in two groups as brands and others (without brands). Brands are products sold in all markets. When given a single right of choice among the brands specified by the participants, it was determined that Banvit is the most preferred brand with a rate of $77.81 \%$. This ratio rises to $86.54 \%$ when more than one brand is given the right to choose. As a result of the statistical analysis, the preference of Banvit brand among other brands showed a significant difference $(P=0.05)$. One of the biggest reasons for this difference is the effect of brand trust on consumption psychology. The number of live animals for the years of the brand. Figure 3 is also given.

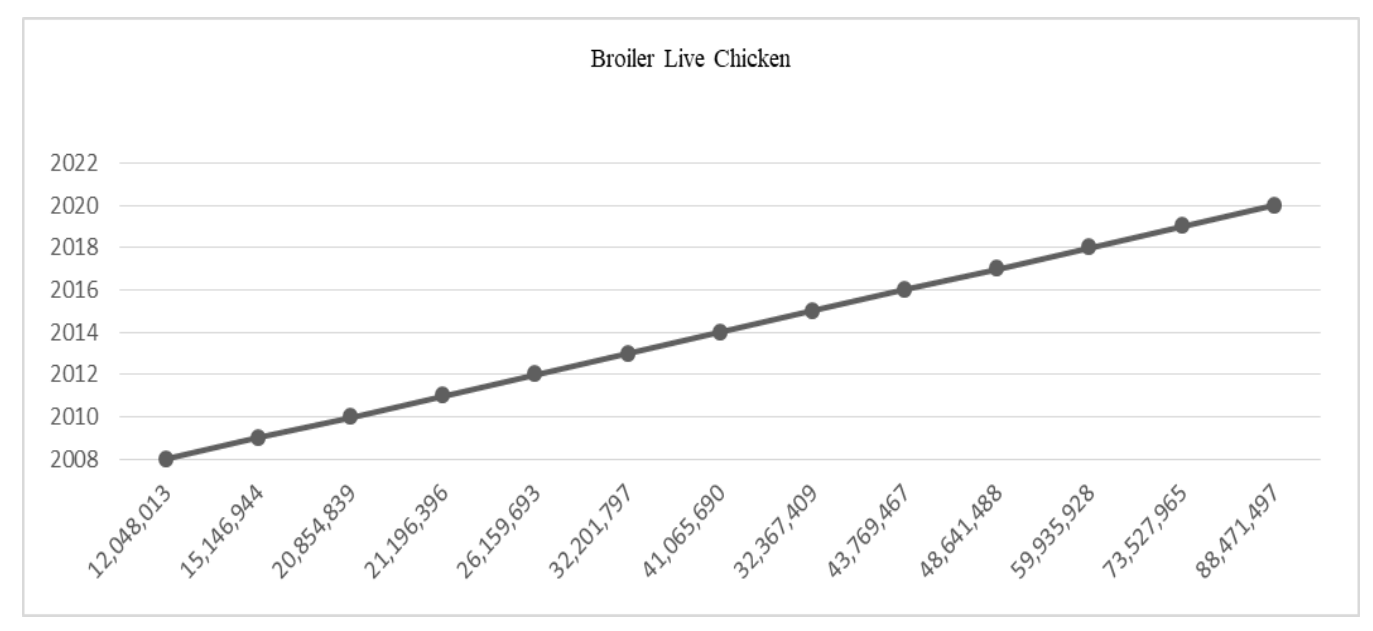

Figure 3 Number of broiler live chickens over the years (22)

The number of live broilers for the years is given in Figure 3. It has been determined that the brand has the potential to continuously increase its production amount between 2008 and 2022. Data for 2022 cover the period until 30 June. When the production of the brand during the COVID-19 pandemic is examined, it shows that there is no decrease in the production capacity. 


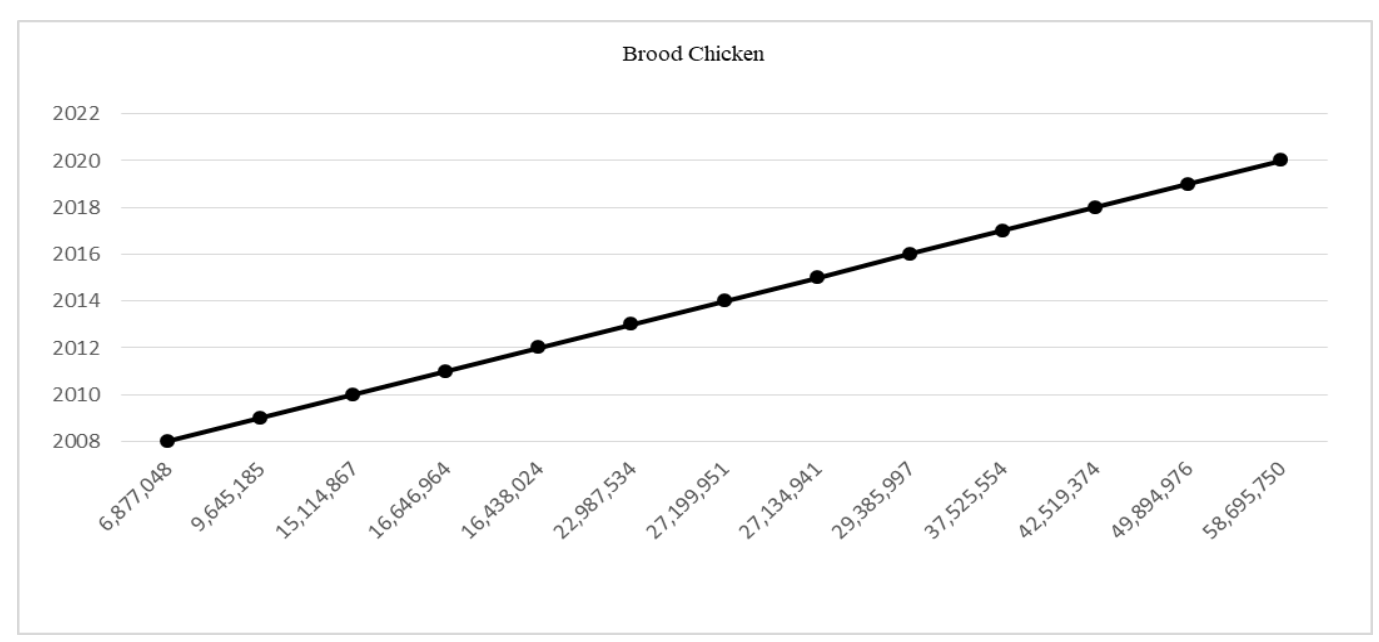

Figure 4 Number of brood chicken over the years (22)

In Figure 4 the numbers of brood chickens are given. When the number of breeding chickens is examined between 2008 and 2022, it appears that there is a continuous increase potential.

\section{Conclusion}

During the COVID-19 Pandemic and the quarantine period, the consumed of food sources with high carbohydrate content increased; When the amount of white meat consumed as a protein source was compared with the amount of white meat consumed in the previous period, it was observed that there was no significant difference.

\section{References}

[1] Sun J, He WT, Wang L, Lai A, Ji X, Zhai X, Li G, Suchard MA, Tian J, Zhou J, Veit M, Su S. CoVID-19: epidemiology, evolution, and cross-disciplinary perspectives. Trends in Molecular Medicine. 2020; 20: 5.

[2] WHO (World Health Organization), Coronavirus disease 2019 (COVID-19) Situation Report. 2020; 51.

[3] Buckley DJ, Morissey PA, Gray JI. Influence of Dietary Vitamin E on the Oxidative Stability and Quality of Pig Meat. J. Anim. Sci. 1995; 73: 3122-3130.

[4] Dufrasne I, Marche C, Clinquart A, Hornick JL. Effects of dietary vitamin E supplementation on performance and meat characteristics in fattening bulls from the Belgian Blue breed. Livestock Produc. Sci. 2000; 65: 197-201.

[5] Engel JF, Kollat DT, Blackwell RD. Consumer behavior. New York: Holt, Rinehart and Winston. 1968.

[6] FAO, Food Outlook - Biannual report on global food markets - November 2018; 104.

[7] Goddard E. The impact of COVID-19 on food retail and food service in Canada: Preliminary assessment, Canadian Journal of Agricultural Economics/Revue canadienne d'agroeconomie. 2020; 1-5.

[8] Gray JI, Gomaa EA, Buckley DJ. Oxidative Quality and Shelf Life of Mets. Meat Sci. 1996; 43: S111-S123.

[9] Haugtvedt CP. Consumer psychology. Encyclopedia of social psychology. Newbury Park, CA: Sage. 2006.

[10] Hocking PM, Genetik seleksiyon ve damızlık seçiminin kanatlı sektörünün ekonomik gelişimine katkısı. 3rd Int. Poultry Meat Congress, 22-26 April Antalya, Proceedings. 2015; 1-10.

[11] Kamen J. The start of division 23 (consumer psychology) of the American Psychological Association. Unpublished article. 1995.

[12] Kassarjian H. Consumer psychology. Annual Review of Psychology. 1982; 33: 619-649.

[13] Knotek IIES, Schoenle R, Dietrich A, Kuester K, Müller G, Myrseth KOR, ve Weber M. Consumers and COVID-19: A Real-Time Survey, Economic Commentary. 2020; 1-6.

[14] Leaf A, Kang JX. Omega-3 fatty acids and cardiovascular disease. In: the return of omega-3 fatty acids into the food supply. A.P. Simopoulos, ed. S. Karger AG, Basel. 1998; 24-37. 
[15] Muloney JC. Th e First Eighty Years of Advertising Research, Paper presented at the Sixth Annual Advertising and Consumer Psychology Conference, Chicago. 1987.

[16] Shaikh A. Effective Factors in Changing the Buying Behavior of Consumer Due to Covid-19", Studies in Indian Place Names. 2020; 40(68): 408-414.

[17] Stanciu S, Radu RI, Sapira V, ve Dumitrache B. Consumer Behavior in Crisis Situations- Research on the Effects of COVID-19 in Romania", Annals of Dunarea de Jos University of Galati. 2020; 5-13.

[18] Baker SR, Farrokhnia RA, Meyer S, Pagel M. ve, Yannelis C. How does household spending respond to an epidemic? Consumption during the 2020 COVID-19 pandemic, National Bureau of Economic Research. 2020; No. 26949.

[19] USDA, National Nutrient Database for Standard Reference. 28 slightly revised May 2016 Software v.2.6.1.The National Agricultural Library. 2016.

[20] Benjamin LT. Jr, Science for sale: Psychology's earliest adventures in American advertising. In J. Williams, W. Lee, \& C. Haugtvedt (Eds.), Diversity in advertising. Mahwah, NJ: Lawrence Erlbaum. 2004.

[21] Zurayk R. Pandemic and food security. Journal of Agriculture, Food Systems, and Community Development. 2020; 9(3): 1-5.

[22] Banvitas.com/pdf/Banvit-Faaliyet-Raporu-2008-2020. 